\title{
Distal monosomy 10p
}

INSERM

\section{Source}

INSERM. (1999). Orphanet: an online rare disease and orphan drug data base. Distal monosomy 10p. ORPHA:1580

Distal monosomy 10p is a rare chromosomal disorder in which the tip of the short arm ( $p$ arm) of chromosome 10 is deleted resulting in a variable phenotype depending on the size of the deletion. The deletion may involve only the terminal 10p15 band, or extend towards the centromere to bands 10p14 or 10p13. 